\title{
Factors influencing occupational accidents: a multidimensional analysis in the electricity sector
}

\author{
Fatores que influenciam os acidentes de trabalho: uma análise \\ multidimensional no setor elétrico
}

\author{
Adriana Maria Silva Alves ${ }^{1}$ (D), Cid Gonçalves Filho ${ }^{2}$ (D), Nathália de Melo Santos ${ }^{3}$ (D), \\ Gustavo Quiroga Souki ${ }^{4}$ (D) \\ ${ }^{1}$ Companhia Energética de Minas Gerais-Cemig, Belo Horizonte, MG, Brasil. E-mail: adriananm@cemig.com.br \\ ${ }^{2}$ Universidade Fumec - FUMEC, Programa de Doutorado e Mestrado em Administração, Belo Horizonte, MG, \\ Brasil. E-mail: cid@fumec.br \\ ${ }^{3}$ Instituto Federal de Brasília - IFB, Gestão e Negócios, Brasília, DF, Brasil. E-mail: nsantos.adm@gmail.com \\ ${ }^{4}$ Universidade do Algarve - UALG, Faculdade de Economia, Centro de Investigação em Turismo, Sustentabilidade \\ e Bem-Estar (CinTurs), Faro, Algarve, Portugal. E-mail: gustavo@souki.net.br
}

How to cite: Alves, A. M. S., Gonçalves Filho, C., Santos, N. M., \& Souki, G. Q. (2020). Factors influencing occupational accidents: a multidimensional analysis in the electricity sector. Gestão \& Produção, 27(2), e4609. https://doi.org/10.1590/0104-530X4609-20

\begin{abstract}
Occupational accidents are a public health problem; therefore, it is necessary to conduct research that contributes to accident prevention and health promotion. To this end, this study aimed to investigate the main factors influencing work accidents at an electric power company. A survey of 1,027 in-house and outsourced employees of a large electric utility was conducted. The participants included injured and non-injured professionals. Organizational, personal/behavioral, and work/task factors were found to have statistically significant effects on work accident occurrence. As an academic and managerial contribution, the identification of the main factors that influence work accidents in the electric sector favors the development of strategies and actions for its control and mitigation.
\end{abstract}

Keywords: Occupational accidents; Public health; Accident-prevention; Electricity sector; Outsourcing.

Resumo: Os acidentes de trabalho são um problema de saúde pública e, por isso, faz-se necessária a condução de pesquisas que auxiliem na prevenção de acidentes e na promoção da saúde. O objetivo deste trabalho foi investigar os principais fatores que influenciam os acidentes de trabalho em uma concessionária de energia elétrica, visando auxiliar na prevenção de acidentes. Para alcançar o objetivo proposto, foi realizada uma pesquisa com 1.027 empregados próprios ou terceirizados de uma grande empresa do setor elétrico, abrangendo profissionais acidentados e não acidentados. Os resultados obtidos demonstram que fatores organizacionais, pessoais/comportamentais e do trabalho/tarefa apresentam impactos estatisticamente significativos sobre os acidentes de trabalho. Como contribuição acadêmica e gerencial, a identificação dos principais fatores que influenciam os acidentes de trabalho no setor elétrico favorece o desenvolvimento de estratégias e ações para o seu controle e mitigação.

Palavras-chave: Acidentes de trabalho; Saúde pública; Prevenção de acidentes; Setor elétrico; Terceirização.

Received Jan. 31, 2018 - Accepted Oct. 5, 2018

Financial support: Projeto de Pesquisa e Desenvolvimento Tecnológico Cemig - Aneel - P\&D D443.

This is an Open Access article distributed under the terms of the Creative Commons Attribution License, which permits unrestricted use, distribution, and reproduction in any medium, provided the original work is properly cited. 


\section{Introduction}

Occupational accidents are very detrimental to worker health. In addition to having emotional, psychological, and social consequences, occupational accidents constitute a public health problem that creates costs for companies and the country (AmponsahTawiah \& Mensah, 2016; Muchiri et al., 2019; Munhê, 2009).

The Brazilian Social Security (Brasil, 2011), in Law 8.213/1991-Art. 21 (Brasil, 1991), defines work-related accidents as accidents that occur during the execution of activities at a work site or during the work of special insured persons. These are accidents that cause bodily injury or permanent or temporary functional disturbance that can result in death or the loss or reduction of the capacity to work. This broad generic definition indicates an attempt to account for several aspects of work accidents. It also demonstrates the complexity of the subject.

According to the International Labour Organization (ILO, 2016), every 15 seconds somewhere in the world, a worker dies from an accident or work-related illness, and 153 workers are injured on the job. The organization has estimated that poor health and safety practices consume approximately $4 \%$ of the global gross domestic product. Of the 549,405 work accidents recorded in Brazil in 2017, 2,585 were in the electricity sector (Brasil, 2018). It is, therefore, necessary to devise effective safety management systems to reduce the risk of occupational accidents.

Several tools, such as management systems that can be evaluated and certified, are being adopted by organizations to evaluate their goods, services, and processes to improve their risk management strategies (Airagnes et al., 2018; Alves, 2012; Drakopoulos \& Theodossiou, 2016; Salminen, 2016; Sheikhalishahi et al., 2017; Siren \& Knudsen, 2017; Thurston \& Glendon, 2018).

Occupational accidents are a multidimensional problem with many variables that can be predictive of yet other variables, such as health, satisfaction, and absenteeism (Amponsah-Tawiah \& Mensah, 2016; Drakopoulos \& Theodossiou, 2016; Šarotar Žižek \& Mulej, 2016; Thurston \& Glendon, 2018; Tomás et al., 1999). Thus, accident occurrence is the result of a complex web of interrelated personal/behavioral factors (Airagnes et al., 2018; Cheung, 2014; Gembalska-kwiecień, 2017; Rakhshandehroo et al., 2015; Sakina \& Omar, 2018), organizational factors (Eskandari et al., 2017; Muchiri et al., 2019; Sawhney \& Cigularov, 2018; Thurston \& Glendon, 2018; Yilmaz \& Tosun, 2018), and work/task factors (Mullen et al., 2017; Sawhney \& Cigularov, 2018; Sheikhalishahi et al., 2017; Yilmaz \& Tosun, 2018). The results of these studies indicate that occupational accidents can be attributed to internal (worker characteristics) and external factors (work environment characteristics of specific tasks and the whole organization). Thus, occupational accidents may be related to the characteristics of the work and the organizational environment. They may also be associated with the behavioral and psychological characteristics of employees.

Several studies have sought to explain accidents from the perspective of complexity, which is based on a systemic model, rather than analyses of the specific mechanisms behind the cause-and-effect relationship (Hollnagel, 2009; Oliver et al., 2002). Therefore, this work aims to deepen theoretical and practical discussions on the factors that contribute to work accidents, using an integrative perspective. Worker behaviors and organizational and work/task variables were considered. The objective was to provide empirical evidence for a systemic approach to solutions.

The following research questions were formulated: What are the contributory personal/behavioral, organizational, and work/task factors to the occurrence of occupational accidents? To what degree is each component of the personal/behavioral, organizational, and work/task factors present in the sample (Salience)? What is the 
influence of each component of the personal/behavioral, organizational, and work/job factors on work accident occurrence (Impact)?

The goal of this study was to investigate the influence of personal/behavioral, organizational, and work/task factors on work accidents, with an emphasis on their salience and impact. The study was conducted at a large electric power company with facilities in several Brazilian states because the industry provides a basic and essential service for businesses and the wider society. According to Fundação Coge (FUNCOGE, 2011), the electricity sector is important for the development of the country and the well-being of the population; however, it has a high occurrence of work accidents. This situation highlights the need for the development of mitigation strategies.

\section{Theoretical framework}

During the execution of their duties, workers are at risk for occupational accidents, and the risks are higher in some professions than in others (Sakina \& Omar, 2018; Salminen, 2016; Sheikhalishahi et al., 2017). Companies have typically used a mono-causal approach to the analysis of occupational accidents. A single fundamental cause of an accident is sought, and the focus is on the individuals or their environment. The attention is centered on human error resulting from unsafe actions or environmental conditions. However, this analytical approach disregards the influence of factors such as work situations, organizational conditions, and worker knowledge on task execution and risk avoidance.

The exemplar of this perspective is Heinrich's (1959) domino theory, which argues that accidents and the resulting injuries have antecedents. Heinrich used a sequence of dominoes to demonstrate that personality can be a source of human failures that result in unsafe actions; thus, accident occurrence is related to previous conditions. This traditional approach still has support (Sakina \& Omar, 2018; Chi \& Han, 2013; Hosseinian \& Torghabeh, 2012).

Other models are recognized and applied to work accident analysis. Multi-causal and systemic models have added new elements, including the recognition of the relationship between the worker and the physical environment. Thus, the explanations of the causes of occupational accidents have become more dynamic and comprehensive (Munhê, 2009). Multi-causal accident models consider the influence of diverse, complex interdependent factors. Thus, an accident-influencing factor need not necessarily directly cause damage but may be indirectly associated with the accident, such as organizational or cultural aspects (Eskandari et al., 2017; Muchiri et al., 2019; Sawhney \& Cigularov, 2018; Thurston \& Glendon, 2018; Yilmaz \& Tosun, 2018; Gembalska-kwiecień, 2017; Keffane, 2015; Motter \& Santos, 2017; Rashid et al., 2014; Šarotar Žižek \& Mulej, 2016; Zwetsloot et al., 2017).

Thus, an accident-influencing factor need not necessarily directly cause damage but may be indirectly associated with the accident, such as organizational aspects. This article contemplates the relationships between organizational and personal factors and the characteristics of the work and tasks. Thus, the work' technical and social components interact with the workers' attitudes, generating consequences. The technical and social systems were analyzed from this perspective, considering the role of personal predispositions and the influences exerted on them by these systems. Hence, the present study argues that characteristics of the social system and the technical attributes influence human behavior, favoring occupational accident's occurrence (Kazeminia et al., 2019; Lehockey et al., 2018; Shen et al., 2018; Prescod 
\& Zeligman, 2018; Valero Pacheco \& Isabel Riaño-Casallas, 2017; Mullen et al., 2017; Sawhney \& Cigularov, 2018).

The variables were classified into three groups: personal/behavioral, organizational, and work/task factors. The psychosocial variables, such as demographic factors, personality traits, attitudes, and behaviors, which are antecedents of work accidents, were classified as personal/behavioral factors (Gembalska-kwiecień, 2017; Rakhshandehroo et al., 2015; Amponsah-Tawiah \& Mensah, 2016; Lee et al., 2017; Kazeminia et al., 2019; Shen et al., 2018).

Typically, organizational factors are abstract and may not be close to an accident. Also, an accident can occur at a different moment from its antecedents. Thus, organizational factors do not always appear in a company's accident reports. The literature mentions the influence of deadline pressure on worker behavior and, thus, accident occurrence (Liang et al., 2018; Sheikhalishahi et al., 2017; Jackson et al., 2012).

The characteristics of the social system, including the technical attributes, have direct and indirect effects on work behavior. Thus, the technical and social components of the work environment were considered in this study. The role of personal predispositions and the influences exerted on them by these technical and social systems were examined (Gembalska-kwiecień, 2017; Jackson et al., 2012; Sakina \& Omar, 2018; Sheikhalishahi et al., 2017; Yilmaz \& Tosun, 2018).

Table 1 presents the dimensions and variables included in the present study and the authors who developed related research.

Table 1. Personal/behavioral, organizational, and work/task dimensions and variables.

\begin{tabular}{|c|c|c|}
\hline Dimensions & Variables & References \\
\hline \multirow{13}{*}{ 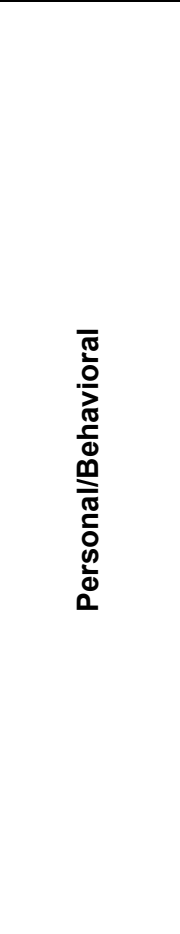 } & Physical activities & Rakhshandehroo et al. (2015) \\
\hline & Self-efficacy & Knudsen \& Gron (2010) \\
\hline & Concentration ability & $\begin{array}{l}\text { Fadyl et al. (2010), Gembalska-kwiecień } \\
\text { (2017), Rakhshandehroo et al. (2015) }\end{array}$ \\
\hline & $\begin{array}{c}\text { Planning and } \\
\text { organization skills } \\
\text { (Conscientiousness) }\end{array}$ & $\begin{array}{l}\text { Clarke and Robertson (2005), Kazeminia et al. } \\
\text { (2019), Lehockey et al. (2018), } \\
\text { Sheikhalishahi et al., 2017), Shen et al. (2018) }\end{array}$ \\
\hline & Commitment & $\begin{array}{l}\text { Amponsah-Tawiah \& Mensah (2016), } \\
\text { Lee et al. (2017), Pinto Silva et al. (2018) }\end{array}$ \\
\hline & $\begin{array}{l}\text { Alcohol and drug } \\
\text { consumption }\end{array}$ & $\begin{array}{l}\text { Airagnes et al. (2018), Cheung (2014), } \\
\text { Kouvonen et al. (2016), Magnavita \& } \\
\text { Garbarino (2017), Sakina \& Omar (2018) }\end{array}$ \\
\hline & $\begin{array}{l}\text { Discipline and rule } \\
\text { adherence } \\
\text { (Agreeableness) }\end{array}$ & $\begin{array}{l}\text { Clarke \& Robertson (2005), Kazeminia et al. } \\
\text { (2019), Lehockey et al. (2018), Shen et al. } \\
(2018)\end{array}$ \\
\hline & Experience & $\begin{array}{l}\text { Koranyi et al. (2018), Salminen (2016), } \\
\text { Sheikhalishahi et al. (2017) }\end{array}$ \\
\hline & Medicines & Kouvonen et al. (2016), Salminen (2016) \\
\hline & Financial situation & Gonçalves et al. (2017) \\
\hline & Sleep & $\begin{array}{l}\text { Kouvonen et al. (2016), Magnavita \& } \\
\text { Garbarino (2017) }\end{array}$ \\
\hline & Super-optimism & Knudsen \& Gron (2010) \\
\hline & $\begin{array}{l}\text { Temperamental } \\
\text { volatility }\end{array}$ & Cheung (2014), Gonçalves et al. (2017) \\
\hline
\end{tabular}


Table 1. Continued...

\begin{tabular}{|c|c|c|}
\hline Dimensions & Variables & References \\
\hline \multirow{5}{*}{ 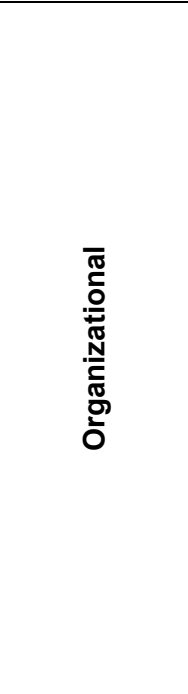 } & $\begin{array}{l}\text { Employee attitudes to } \\
\text { safety standards }\end{array}$ & $\begin{array}{l}\text { Eskandari et al. (2017), Farina et al. (2013), } \\
\text { Gembalska-kwiecień (2017), Muchiri et al. } \\
\text { (2019), Mullen et al. (2017), Šarotar Žižek \& } \\
\text { Mulej (2016), Sawhney \& Cigularov (2018), } \\
\text { Thurston and Glendon (2018), Yilmaz \& Tosun } \\
\text { (2018) }\end{array}$ \\
\hline & $\begin{array}{l}\text { Communication } \\
\text { consistency }\end{array}$ & Arendt et al. (2013), Zwetsloot et al. (2017) \\
\hline & Communication & $\begin{array}{l}\text { De Silva et al. (2017), Eskandari et al. (2017), } \\
\text { Muchiri et al. (2019), Mullen et al. (2017), } \\
\text { Sawhney \& Cigularov (2018), } \\
\text { Sheikhalishahi et al. (2017) }\end{array}$ \\
\hline & $\begin{array}{l}\text { Culture and security } \\
\text { climate }\end{array}$ & $\begin{array}{l}\text { Eskandari et al. (2017), Gembalska-kwiecień } \\
\text { (2017), Keffane (2015), Motter \& Santos } \\
\text { (2017), Rashid et al. (2014), Šarotar Žižek \& } \\
\text { Mulej (2016), Thurston \& Glendon (2018), } \\
\text { Zwetsloot et al. (2017) }\end{array}$ \\
\hline & $\begin{array}{l}\text { Participative decision- } \\
\text { making }\end{array}$ & Liu et al. (2015), Muchiri et al. (2019) \\
\hline \multirow{7}{*}{ 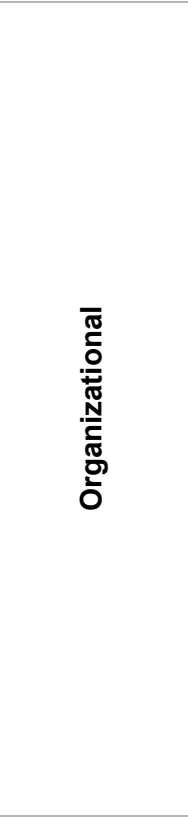 } & Stability & $\begin{array}{l}\text { De Silva et al. (2017), Farina et al. (2013), } \\
\text { Prescod \& Zeligman (2018), Valero Pacheco \& } \\
\text { Isabel Riaño-Casallas (2017), Vu et al. (2017), } \\
\text { Yilmaz \& Tosun (2018) }\end{array}$ \\
\hline & Security program & $\begin{array}{l}\text { Amponsah-Tawiah \& Mensah (2016), De } \\
\text { Silva et al. (2017), Eskandari et al. (2017), } \\
\text { Farina et al. (2013), Gra \& Miha (2011), } \\
\text { Pinion et al. (2017), Šarotar Žižek and Mulej } \\
\text { (2016), Yilmaz \& Tosun (2018) }\end{array}$ \\
\hline & $\begin{array}{l}\text { Resistance to a safety } \\
\text { program }\end{array}$ & $\begin{array}{l}\text { Amponsah-Tawiah \& Mensah (2016), De } \\
\text { Silva et al. (2017), Farina et al. (2013), Gra \& } \\
\text { Miha (2011), Pinion et al. (2017), Yilmaz \& } \\
\text { Tosun (2018) }\end{array}$ \\
\hline & $\begin{array}{l}\text { Employee skills and } \\
\text { competencies }\end{array}$ & $\begin{array}{l}\text { De Silva et al. (2017), Farina et al. (2013), } \\
\text { Felce et al. (2016), Heine et al. (2016) }\end{array}$ \\
\hline & Job satisfaction & $\begin{array}{l}\text { Eskandari et al. (2017), Fehlberg et al. (2001), } \\
\text { Souza et al. (2017), Valero Pacheco \& Isabel } \\
\text { Riaño-Casallas (2017) }\end{array}$ \\
\hline & Salaries and benefits & $\begin{array}{l}\text { De Silva et al. (2017), Eskandari et al. (2017), } \\
\text { Yilmaz \& Tosun (2018) }\end{array}$ \\
\hline & Training & $\begin{array}{l}\text { De Silva et al. (2017), Eskandari et al. (2017), } \\
\text { Sheikhalishahi et al. (2017) }\end{array}$ \\
\hline \multirow{4}{*}{ 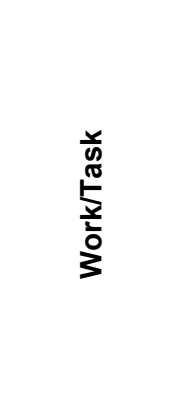 } & $\begin{array}{l}\text { Physical work } \\
\text { environment }\end{array}$ & $\begin{array}{l}\text { Jackson et al. (2012), Gembalska-kwiecień } \\
\text { (2017), Sheikhalishahi et al. (2017), Yilmaz \& } \\
\text { Tosun (2018) }\end{array}$ \\
\hline & $\begin{array}{l}\text { Manager attitudes to } \\
\text { safety standards }\end{array}$ & $\begin{array}{l}\text { Eskandari et al. (2017), Gembalska-kwiecień } \\
\text { (2017), Muchiri et al. (2019), Mullen et al. } \\
\text { (2017), Sawhney \& Cigularov (2018), } \\
\text { Sheikhalishahi et al. (2017) }\end{array}$ \\
\hline & Workload & $\begin{array}{l}\text { De Silva et al. (2017), Koranyi et al. (2018), } \\
\text { Liang et al. (2018), Sheikhalishahi et al. (2017) }\end{array}$ \\
\hline & $\begin{array}{l}\text { Variability (Task } \\
\text { planning) }\end{array}$ & $\begin{array}{l}\text { Jackson et al. (2012), Sheikhalishahi et al. } \\
\text { (2017) }\end{array}$ \\
\hline
\end{tabular}

Source: Elaborated by the authors. 
The theoretical references and the personal/behavioral, organizational, and work/task dimensions of the present study are presented. After that, the methods are described.

\section{Methods}

This article is derived from a research and development project conducted at one of Brazil's largest electric power companies, which has operations in several states. A state-of-the-art analysis of the technical-scientific literature was performed to identify the constructs to be included in the study. A survey was then conducted, and statistical analysis of the data was completed.

The survey comprised 1,027 respondents: 717 employees of the power company and 310 outsourced employees of its contractors. It worth noting that the power company had 6,127 in-house and 17,847 outsourced employees at the time of data collection. Thus, the sampling error for the in-house employees studied was $3.4 \%$ at a $95 \%$ confidence level. For the outsourced employees, the sampling error was $5.5 \%$ at a $95 \%$ confidence level. The sample was not limited to employees who were involved in work accidents.

The printed questionnaires were delivered through the company's internal mail system. The participants filled in the questionnaires without providing personal identification and returned them by the same means. However, the respondents had to indicate whether their employment was through the utility or one of its outsourcers.

The questionnaires were tabulated with IBM SPSS Statistics for Windows ${ }^{\circledR}$ Version 22.0 software, and descriptive and multivariate statistical analyses were performed. The descriptive statistics were used for exploring the respondents' characteristics, such as gender, age, and length of tenure with the company and the sector.

The amount of missing data was checked to avoid problems in the analyses. The missing data represented only $0.65 \%$ of the database; consequently, no additional action was necessary (Kaiser, 2014). The normality of the data was tested to determine the most appropriate analytical tool. As was expected, the non-normality in the data was confirmed, thereby supporting the choice of tests that do not presuppose normality (Ahmad \& Khan, 2015). As recommended by Tabachnick \& Fidell (2007), the outliers are identified and treated appropriately (substitution by the means) to ensure an unbiased approach to the analysis. Linearity analysis demonstrates that the association between two variables can be a linear equation. Hence, the increment of one variable can affect the performance of another variable consistently and linearly (Hair et al., 2009). This research's results showed that there was no violation of this association parameter. After the completion of the initial descriptive analyses, the multivariate statistical analyses are performed. The first was the analysis of the quality of the measurement, based on the parameters presented in Table 2.

Table 2. Criteria for the adequacy of the factor solution.

\begin{tabular}{lclc}
\hline \multicolumn{1}{c}{ Measure } & $\begin{array}{c}\text { Acceptance } \\
\text { parameters }\end{array}$ & \multicolumn{1}{c}{ Measure } & $\begin{array}{c}\text { Acceptance } \\
\text { parameters }\end{array}$ \\
\hline Correlation & $>0.300$ & Factor load (CF) & $>0.400$ \\
\hline $\begin{array}{l}\text { Kaiser-Meyer-Olkin sampling } \\
\text { adequacy measure }\end{array}$ & $>0.500$ & $\begin{array}{l}\text { Variance } \\
\text { explained (VE) }\end{array}$ & $>60 \%$ \\
\hline Bartlett's sphericity test (BTS) & $p<0.05$ & Cronbach's alpha & $>0.70$ \\
\hline Communalities & $>0.500$ & & \\
\hline
\end{tabular}

Source: Authors, based on Hair et al. (2009) and Tabachnick \& Fidell (2007). 
The data obtained in this study were adequate for all of the parameters presented in Table 2. The proposed structural model was analyzed using Structural Equation Modeling. IBM SPSS for Windows ${ }^{\circledR}$ Version 22 and SmartPLS ${ }^{\circledR}$ 2.0.M $\mathrm{M}_{3}$ are used.

The scales varied based on the type of information sought. The questionnaire consisted of dichotomous (yes-no), and 11-point agree-disagree scales with values ranging from 0 (totally disagree) to 10 (totally agree). Open-ended questions were also included. Two parameters, salience, and impact were selected for the comparisons of the analyzed constructs. Salience represented the frequency of occurrence of a characteristic, i.e., respondent agreement on the manifestation of a phenomenon. The higher the index value, $0-100 \%$, the higher was the agreement (attitudes and opinions) and frequency (behaviors). Impact represented the importance or total effect of the variables on occupational accidents. The higher the outcome, the greater was the predictive relevance of the variable.

The analysis of the in-house and outsourced employees is presented in the next section aiming to identify the differences between respondents' opinions and behaviors.

\section{Results}

The sample's characteristics are presented before discussing the salience and impact of personal/behavioral, organizational, and work/task factors on occupational accidents. The results indicated that a majority of respondents are males who completed high school, both for the electric utility' and the outsourced' employees. A majority of the in-house employees were 41-50 years old, and a majority of the outsourced workers were $<30$ years old. Besides, the outsourced employees' education levels were lower than those of the in-house employees (Table 3).

Table 3. Characteristics of the sample.

\begin{tabular}{|c|c|c|c|}
\hline & Characteristics & $\begin{array}{c}\text { In-house } \\
\text { Employees \% }\end{array}$ & $\begin{array}{l}\text { Outsourced } \\
\text { employees \% }\end{array}$ \\
\hline \multirow{2}{*}{ Sex } & Female & 3 & 10 \\
\hline & Male & 97 & 90 \\
\hline \multirow{8}{*}{$\begin{array}{l}\text { Schoolin } \\
\text { g level }\end{array}$} & Illiterate & 0 & 2 \\
\hline & Fundamental (up to 4 th year) & 1 & 25 \\
\hline & Fundamental (up to 9th year) & 1 & 21 \\
\hline & High school & 43 & 39 \\
\hline & Undergraduate (Incomplete) & 19 & 7 \\
\hline & Undergraduate (Complete) & 29 & 4 \\
\hline & Specialization & 6 & 2 \\
\hline & Master's/doctorate degree & 1 & 0 \\
\hline \multirow{4}{*}{$\begin{array}{c}\text { Age } \\
\text { (years) }\end{array}$} & $<30$ & 16 & 39 \\
\hline & $31-40$ & 29 & 33 \\
\hline & Between 41-50 & 51 & 20 \\
\hline & $51+$ & 4 & 8 \\
\hline
\end{tabular}

Source: Research data.

The results revealed a relationship between the analyzed variables and work accidents. The variables were classified along three dimensions: personal/behavioral, 
organizational, and work/task factors. As was indicated, the analysis was performed for in-house and outsourced employees. Because of space limitations, only the variables with the most significant impact on occupational accidents will be discussed. That are many elements that cause occupational accidents. Therefore, it is necessary to pay attention to other factors that potentially contribute to the occurrence of accidents at work.

Some sample information will be highlighted to explain the analyses used in this research. The results revealed that $9 \%$ of the in-house employees had taken time off during the previous 12 months because of occupational accidents or illnesses. Regarding the perception of accident risk, $26 \%$ reported having experienced risky situations or having seen their colleagues in such circumstances. Of the outsourced employees, $13 \%$ said having taken time off within the previous 12 months because of illness, and $32 \%$ reported having experienced risky situations or having seen their colleagues in such conditions.

Table 4 presents the salience and impact of the variables related to the personal/behavioral factors on work accidents.

Table 4. Salience and impact of the variables related to personal/behavioral factors on work accidents.

\begin{tabular}{|c|c|c|c|c|c|}
\hline & \multirow[b]{2}{*}{ Variables } & \multicolumn{2}{|c|}{ Salience } & \multicolumn{2}{|c|}{ Impact } \\
\hline & & $\begin{array}{l}\text { In-house } \\
\text { employees }\end{array}$ & $\begin{array}{l}\text { Outsourced } \\
\text { employees }\end{array}$ & $\begin{array}{l}\text { In-house } \\
\text { employees }\end{array}$ & $\begin{array}{l}\text { Outsourced } \\
\text { employees }\end{array}$ \\
\hline \multirow{13}{*}{ 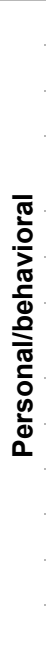 } & Physical activities & $54 \%$ & $45 \%$ & - & - \\
\hline & Self-efficacy & $\uparrow 82 \%$ & $\uparrow 81 \%$ & - & $-2 \%$ \\
\hline & Concentration capacity & $\uparrow 81 \%$ & $\uparrow 83 \%$ & - & $\downarrow-1 \%$ \\
\hline & $\begin{array}{l}\text { Planning and organization } \\
\text { skills (Conscientiousness) }\end{array}$ & $\uparrow 82 \%$ & $\uparrow 85 \%$ & - & $\downarrow-1 \%$ \\
\hline & Commitment & $\uparrow 84 \%$ & $\uparrow 77 \%$ & - & $\downarrow-1 \%$ \\
\hline & Alcohol and drug use & $35 \%$ & $\downarrow 23 \%$ & $\uparrow+12 \%$ & $\downarrow+1 \%$ \\
\hline & $\begin{array}{l}\text { Discipline and rule adherence } \\
\text { (Agreeableness) }\end{array}$ & $\downarrow 20 \%$ & $\downarrow 29 \%$ & $\downarrow+1 \%$ & $+4 \%$ \\
\hline & Experience & $56 \%$ & $44 \%$ & - & - \\
\hline & Medicines & $\downarrow 7 \%$ & $\uparrow 77 \%$ & - & - \\
\hline & Financial situation & $\uparrow 67 \%$ & $56 \%$ & $-3 \%$ & $-4 \%$ \\
\hline & Sleep & $\downarrow 30 \%$ & $\downarrow 28 \%$ & - & - \\
\hline & Super-optimism & $47 \%$ & $\downarrow 42 \%$ & - & $\uparrow+17 \%$ \\
\hline & Temperamental volatility & $\downarrow 31 \%$ & $\downarrow 33 \%$ & $\downarrow+1 \%$ & - \\
\hline
\end{tabular}

Source: Research data. Legend: $\downarrow$ Low impact $(<2 \%)$, • moderate impact $(2-5 \%)$, and $\uparrow$ high impact $(\geq 5 \%)$. The values are rounded. Numbers in the columns related to impact: The red color indicates a global negative impact, and the green color indicates an overall positive impact.

The results presented in Table 4 indicate that among the personal/behavioral factors, the in-house employees' alcohol and drug consumption and financial situation were the main contributors to occupational accident occurrence. The reason is that alcohol and drug use, despite the low incidence among the respondents (35\% salience), has a direct effect on occupational accidents (12\%). The financial situation factor had a salience of $67 \%$ and a negative impact $(-3 \%)$ on accident occurrence. 
For the outsourced employees, the main antecedents of work accidents were the personal/behavioral factors: self-efficacy, discipline, and rule adherence (agreeableness), super-optimism, and financial situation.

The value for self-efficacy (belief in the ability to complete a task) was $81 \%$. Thus, respondents believed in their abilities to fulfill their goals by acting on their decisions. This factor had a negative influence $(-2 \%)$ on work accidents.

Discipline and rule adherence (observance of work instructions and organization rules and regulations) was an individual factor with low salience (29\%). It demonstrates that the respondents did not have problems following rules. However, companies must consider this factor because it is responsible for $4 \%$ of work accidents.

Super-optimism (to believe that nothing wrong will happen to itself) also had medium salience $(56 \%)$, which explained a large part of the work-related accident occurrence $(17 \%)$ in the outsourced employees. The outsourced employees' financial situations had $56 \%$ salience, which indicated a reasonable degree of agreement among the respondents. It had a negative impact $(-4 \%)$ on work-related accident occurrence. Thus, the better the employee's financial situation, the lower was the chance of a work-related accident.

For the in-house employees (Table 5), the organizational factor variables (e.g., communication consistency, culture and security climate, participative decisionmaking, and employment stability), had the most significant influence on accident occurrence.

Table 5. Salience and impact of organizational factor variables on work accidents.

\begin{tabular}{|c|c|c|c|c|c|}
\hline & \multirow[b]{2}{*}{ Variables } & \multicolumn{2}{|c|}{ Salience } & \multicolumn{2}{|c|}{ Impact } \\
\hline & & $\begin{array}{l}\text { In-house } \\
\text { employees }\end{array}$ & $\begin{array}{l}\text { Outsourced } \\
\text { employees }\end{array}$ & $\begin{array}{l}\text { In-house } \\
\text { employees }\end{array}$ & $\begin{array}{l}\text { Outsourced } \\
\text { employees }\end{array}$ \\
\hline \multirow{12}{*}{ 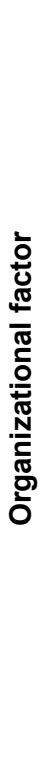 } & $\begin{array}{l}\text { Employee attitudes to } \\
\text { safety standards }\end{array}$ & $\uparrow \mathbf{8 0 \%}$ & $\uparrow 79 \%$ & $-2 \%$ & $\uparrow-10 \%$ \\
\hline & $\begin{array}{l}\text { Communication } \\
\text { consistency }\end{array}$ & $\uparrow \mathbf{6 5 \%}$ & $66 \%$ & $\uparrow-7 \%$ & - \\
\hline & Communication & $\uparrow 76 \%$ & $\uparrow \mathbf{7 8 \%}$ & - & - \\
\hline & $\begin{array}{l}\text { Culture and security } \\
\text { climate }\end{array}$ & $55 \%$ & $58 \%$ & $\uparrow-14 \%$ & $\downarrow-1 \%$ \\
\hline & $\begin{array}{l}\text { Participative decision- } \\
\text { making }\end{array}$ & $\uparrow 75 \%$ & $\uparrow 82 \%$ & $-3 \%$ & - \\
\hline & Employment stability & $\uparrow 63 \%$ & $\downarrow 42 \%$ & $-3 \%$ & $\downarrow-1 \%$ \\
\hline & Security program & $\uparrow 78 \%$ & $\uparrow 72 \%$ & $\downarrow-1 \%$ & $\downarrow-1 \%$ \\
\hline & $\begin{array}{l}\text { Safety program } \\
\text { (resistance) }\end{array}$ & $\downarrow 18 \%$ & $\downarrow 32 \%$ & $3 \%$ & $\downarrow 1 \%$ \\
\hline & $\begin{array}{l}\text { Employee skills and } \\
\text { competencies }\end{array}$ & $\uparrow 78 \%$ & $\uparrow \mathbf{8 0 \%}$ & $\downarrow-1 \%$ & $-3 \%$ \\
\hline & Job satisfaction & $\uparrow 83 \%$ & $\uparrow 86 \%$ & - & $-3 \%$ \\
\hline & Salaries and benefits & $53 \%$ & $54 \%$ & $\uparrow-7 \%$ & $-3 \%$ \\
\hline & Training & $\uparrow \mathbf{8 3 \%}$ & $\uparrow \mathbf{8 1 \%}$ & $\downarrow-1 \%$ & - \\
\hline
\end{tabular}

Source: Rsearch data. Legend: $\downarrow$ Low impact $(<2 \%)$, - moderate impact $(2-5 \%)$, and $\uparrow$ high impact $(\geq 5 \%)$. The values are rounded. Numbers in the columns related to impact: The red color indicates a global negative impact, and the green color indicates an overall positive impact. 
The in-house employees' perceptions of the power company's communication consistency had $65 \%$ salience and a negative impact on work accidents $(-7 \%)$. Thus, the alignment of an organization's training and communication with its practices can contribute to a reduction in work accidents.

Safety culture and climate (a manifestation of the safety-related characteristics of the organizational culture) had a median salience $(55 \%)$ for the in-house employees but a substantial impact on the lower occurrence of workplace accidents $(-14 \%)$. Therefore, a supportive culture and safety climate has a direct effect on occupational accident occurrence.

The participative decision-making factor had high salience $(75 \%)$ for the inhouse employees, and it negatively affected accident occurrence by $3 \%$. It indicates that greater employee participation in the discussions about their work and higher degrees of autonomy can reduce accidents. Furthermore, most of the in-house employees (63\%) tended to agree that they would not be fired (employment stability). This factor explained the $3 \%$ decrease in work accidents. Thus, stability at work helps to reduce accident occurrence.

For the outsourced employees, the following dimensions present influence on occupational accidents: employee attitudes to safety, job satisfaction, organizational culture, and the safety climate and safety program.

Employee attitudes to safety standards (valuation of and compliance with safety standards) had a high degree of agreement among the outsourced workers $(79 \%)$ and a negative impact $(-10 \%)$ on occupational accidents.

Job satisfaction had $86 \%$ salience for the outsourced workers. Thus, professional accident occurrence reduced by $3 \%$ because the employees were satisfied with working for their companies.

For the outsourced workers, the organizational culture and security climate had medium salience $(58 \%)$ but low importance in accident reduction $(-1 \%)$. This result was in contrast to those obtained for the in-house employees. Therefore, there are opportunities for outsourcing companies to improve the culture and security climate.

The safety program had $72 \%$ salience for the outsourced workers and $78 \%$ for the in-house employees. Most of the respondents believed that their companies' safety procedures helped them to perform their duties safely. Besides, they felt that their companies provided adequate, well-maintained safety equipment. They did not believe that the safety procedures hindered job performance. Moreover, they agreed that the outsourcing companies investigated accidents quickly and adequately. However, for both groups, the impact of the safety programs on accident occurrence was low $(1 \%)$. The results suggest the need for a review of the safety programs at the electric utility and its outsourcing companies to determine their effectiveness and the need for possible corrective actions.

For the in-house employees, the components of the work/task factor with the highest salience and impact on work accident occurrence were the managers' attitudes to safety, the physical working environment, and the workload (Table 6). 
Table 6. Salience and impact of work/task factor variables on work accidents.

\begin{tabular}{|c|c|c|c|c|c|}
\hline & \multirow[b]{2}{*}{ Variables } & \multicolumn{2}{|c|}{ Salience } & \multicolumn{2}{|c|}{ Impact } \\
\hline & & $\begin{array}{l}\text { In-house } \\
\text { employees }\end{array}$ & $\begin{array}{l}\text { Outsourced } \\
\text { employees }\end{array}$ & $\begin{array}{l}\text { In-house } \\
\text { employees }\end{array}$ & $\begin{array}{l}\text { Outsourced } \\
\text { employees }\end{array}$ \\
\hline \multirow{4}{*}{$\begin{array}{l}\frac{0}{v} \\
\frac{y}{0} \\
\frac{5}{5} \\
\frac{5}{5} \\
\frac{0}{3}\end{array}$} & $\begin{array}{l}\text { Physical work } \\
\text { environment }\end{array}$ & $50 \%$ & $\downarrow 39 \%$ & $\uparrow \mathbf{5 \%}$ & - \\
\hline & $\begin{array}{l}\text { Manager attitudes } \\
\text { to safety standards }\end{array}$ & $\uparrow \mathbf{7 6 \%}$ & $63 \%$ & $\uparrow-6 \%$ & - \\
\hline & Workload & $\downarrow 22 \%$ & $\downarrow 41 \%$ & $4 \%$ & $3 \%$ \\
\hline & $\begin{array}{l}\text { Variability (task } \\
\text { planning) }\end{array}$ & $\downarrow 36 \%$ & $\uparrow 78 \%$ & $\downarrow 1 \%$ & $3 \%$ \\
\hline
\end{tabular}

Source: Research data. Legend: $\downarrow$ Low impact $(<2 \%)$, - moderate impact $(2-5 \%)$, and $\uparrow$ high impact $(\geq 5 \%)$. The values are rounded. Numbers in the columns related to impact: The red color indicates a global negative impact, and the green color indicates an overall positive impact.

The managers' attitudes to safety (effective involvement of top management in workplace health and safety) had high salience $(76 \%)$ and significantly influenced accident reduction (6\%). This result demonstrated the positive influence of securityoriented managers on the reduction of work-related accidents.

For the in-house employees, the physical working environment (e.g., excessive noise, heat, cold, sun or rain, rugged topography, and contact with chemicals, poisonous animals, or dirt) had $50 \%$ salience and an increase in work accident occurrence (5\%). Hence, a safe physical environment should not expose employees to the cited conditions, contributing to occupational accidents' reduction.

The low agreement of the in-house employees on the workload (perception about the number of tasks to be performed during work hours) indicated that they believed that they are not pressured to perform their activities under tight deadlines and unsafe conditions. Besides, there was an adequate distribution of rest time and work shifts. The workload affected accident occurrence by $4 \%$.

For the outsourced employees, workload, and variability (task planning) had the greatest effect on work accident occurrence (Table 6). Workload salience in the outsourced employee group was $41 \%$, which was higher than that for the in-house employees (22\%). There was also a $3 \%$ increase in work accidents. The outsourced workers were subjected to greater pressure than the in-house employees in performing their tasks, thus increasing the risk of accident occurrence. This result indicates the need for greater attention to be paid to the scheduling of the tasks to be performed during work hours to prevent accidents.

Variability (task planning) refers to how to plan and organize tasks and to unexpected activities that emerge from changes in plans. The study revealed a higher salience for this factor in the outsourced employees $(78 \%)$ than in the in-house employees (36\%). Besides, unplanned changes in tasks increased the occurrence of work-related accidents by $3 \%$. This result demonstrates the need for better planning of the tasks to be performed by outsourced employees.

\section{Conclusions}

The results of this study demonstrate the multifactorial nature of the antecedents of work accidents. Accident occurrence is influenced by personal/behavioral, organizational, and work/task factors. Thus, this exploration of the interrelated 
elements in occupational accident occurrence increases the understanding of the problem.

The profile analysis of the respondents revealed differences in the in-house and outsourced employee characteristics, such as sex, age, and schooling. A higher percentage of women worked at the utility than at its outsourcer companies, and the average age of the in-house employees was higher than that of the outsourced employees. Also, the in-house employees had a higher level of education than the outsourced employees.

Besides the role of alcohol consumption and drugs, the safety culture and organizational climate deserve greater attention in accidents involving in-house employees. These results confirm those of previous studies, thereby reinforcing the fundamental role of the safety culture and climate in the reduction of work accidents (Eskandari et al., 2017; Gembalska-kwiecień, 2017; Keffane, 2015; Motter \& Santos, 2017; Rashid et al., 2014; Šarotar Žižek \& Mulej, 2016; Thurston \& Glendon, 2018; Zwetsloot et al., 2017). The use of alcoholic beverages can cause work accidents (Airagnes et al., 2018; Cheung, 2014; Kouvonen et al., 2016; Magnavita \& Garbarino, 2017; Sakina \& Omar, 2018). Alcohol, as well as some medications, present an adverse effect on the perceptual, cognitive, and motor functions, thus increasing the risk for accidents (Kouvonen et al., 2016; Salminen, 2016; Kurzthaler et al., 2005).

The safety culture and climate permeate the implementation and management of actions related to worker safety. They thus represent differentiating elements of the companies with lower accident rates and a better safety climate. The safety culture is fundamental because it represents worker beliefs, attitudes, and behaviors related to security (Eskandari et al., 2017; Gembalska-kwiecień, 2017; Keffane, 2015; Motter \& Santos, 2017; Rashid et al., 2014; Šarotar Žižek \& Mulej, 2016; Thurston \& Glendon, 2018; Zwetsloot et al., 2017). Thus, the more developed the security culture, the more likely are the workers to have safety beliefs, attitudes, and behaviors.

Super-optimism, as described by Knudsen \& Gron (2010), results in excessive risktaking among outsourced employees, thereby greatly increasing the occurrence of work accidents. People are the ultimate barriers between risk and accident; therefore, their behaviors are crucial to avoiding personal and material damage.

Employee attitudes and perceptions are highly predictive of behavior, such as adherence to safety rules and recommended safety practices (Clarke \& Robertson, 2005; Kazeminia et al., 2019; Lehockey et al., 2018; Shen et al., 2018). However, changing perceptions and attitudes is difficult. It is, therefore, imperative that managers monitor factors such as super-optimism and employee attitudes to safety, which have been particularly problematic in outsourced employees.

Another relevant conclusion of this research relates to the financial situation of the in-house and outsourced employees. Employees with lower incomes are more susceptible to work-related accidents (Gonçalves et al., 2017).

Regarding the academic implications, the discussions about the causes of and analytical approaches to work accidents still engender important debates in the health and safety sectors. This study enriches the theoretical discussions, adding empirical results that show different aspects of the phenomena interpretation. This study revealed that the factors' effects do not always occur at the same time and place as the accident. These findings emphasize the importance of using perspectives that integrate personal/behavioral issues with organizational and work/task variables.

As a managerial contribution, this study identified several of the influences on occupational accidents. This will allow companies to develop action plans that consider 
the factors analyzed in the study. A focus on isolated actions or too few elements can lead to results that do not match expectations or the investments that were made. Thus, the more holistic the analytical perspective, the greater are the chances that an action plan will succeed.

The limitations of this research must be recognized. The study was conducted at a single large-scale electric power utility operating in several Brazilian states. Therefore, additional studies should include other electric power utilities that might exhibit different characteristics. Another reason the results presented here must be interpreted with caution is that the outsourcer companies were operating within the context of a single electric energy company.

Similar studies should be conducted in different contexts. Examples are organizations in other economic sectors, such as mining, telecommunications, and construction. Other factors that affect accidents not observed in this study can appear in further research. Therefore, diverse types and sizes of organizations located in different regions or countries should be investigated in future research. Finally, to prevent occupational accident occurrence, more efforts are necessary to understand the multiple factors involved considering diverse sectors of the economy and in different places.

\section{References}

Ahmad, F., \& Khan, R. A. (2015). Power comparison of various normality tests. Pakistan Journal of Statistics and Operation Research, 11(3), 331-345. http://dx.doi.org/10.18187/pjsor.v11i3.845.

Airagnes, G., Lemogne, C., Goldberg, M., Hoertel, N., Roquelaure, Y., Limosin, F., \& Zins, M. (2018). Job exposure to the public in relation with alcohol, tobacco and cannabis use: findings from the CONSTANCES cohort study. PLoS One, 13(5), 1-21. http://dx.doi.org/10.1371/journal.pone.0196330. PMid:29715268.

Alves, A. M. S. (2012). Contribuição das análises de acidentes de trabalho no processo de gestão de SST: estudo de caso no contexto das empresas de energia elétrica (Dissertação de mestrado). Faculdade de Ciências Empresariais, São Paulo.

Amponsah-Tawiah, K., \& Mensah, J. (2016). Occupational health and safety and organizational commitment: evidence from the ghanaian mining industry. Safety and Health at Work, 7(3), 225-230. http://dx.doi.org/10.1016/j.shaw.2016.01.002. PMid:27630792.

Arendt, S. W., Paez, P., \& Strohbehn, C. (2013). Food safety practices and managers' perceptions: a qualitative study in hospitality. International Journal of Contemporary Hospitality Management, 25(1), 124-139. http://dx.doi.org/10.1108/09596111311290255.

Brasil. (1991, 25 de Julho). Lei no 8.213, de 24 de Julho de 1991. Dispõe sobre os Planos de Benefícios da Previdência Social e dá outras providências. Brasília, DF: Diário Oficial da República Federativa do Brasil. Retrieved in 2018, January 31, from http://www.planalto.gov.br/ccivil_03/leis//8213cons.htm

Brasil. Ministério da Economia. Secretaria de Previdência. (2011). Anuário estatístico da Previdência Social. Brasília: Secretaria de Previdência. Retrieved in 2016, December 12, from www.previdência.gov.br

Brasil. Ministério do Trabalho e Previdência Social - MTPS. (2018). Anuário Estatístico da Previdência Social - 2017. Brasília: MTPS. Retrieved in 2016, December 12, from http://sa.previdencia.gov.br/site/2019/04/AEPS-2017-abril.pdf

Cheung, N. W. T. (2014). Low self-control and co-occurrence of gambling with substance use and delinquency among chinese adolescents. Journal of Gambling Studies, 30(1), 105124. http://dx.doi.org/10.1007/s10899-012-9351-8. PMid:23224660. 
Chi, S., \& Han, S. (2013). Analyses of systems theory for construction accident prevention with specific reference to OSHA accident reports. International Journal of Project Management, 31(7), 1027-1041. http://dx.doi.org/10.1016/j.jproman.2012.12.004.

Clarke, S., \& Robertson, I. T. (2005). A meta-analytic review of the Big Five personality factors and accident involvement in occupational and non-occupational settings. Journal of Occupational and Organizational Psychology, 78(3), 355-376. http://dx.doi.org/10.1348/096317905X26183.

De Silva, N., Samanmali, R., \& De Silva, H. L. (2017). Managing occupational stress of professionals in large construction projects. Journal of Engineering. Design and Technology, 15(4), 488-504. http://dx.doi.org/10.1108/JEDT-09-2016-0066.

Drakopoulos, S. A., \& Theodossiou, I. (2016). Workers' risk underestimation and occupational health and safety regulation. European Journal of Law and Economics, 41(3), 641-656. http://dx.doi.org/10.1007/s10657-012-9379-3.

Eskandari, D., Jafari, M. J., Mehrabi, Y., Kian, M. P., Charkhand, H., \& Mirghotbi, M. (2017). A qualitative study on organizational factors affecting occupational accidents. Iranian Journal of Public Health, 46(3), 380-388. PMid:28435824.

Fadyl, J. K., McPherson, K. M., Schlüter, P. J., \& Turner-Stokes, L. (2010). Factors contributing to work-ability for injured workers: literature review and comparison with available measures. Disability and Rehabilitation, 32(14), 1173-1183. http://dx.doi.org/10.3109/09638281003653302. PMid:20170279.

Farina, E., Bena, A., Pasqualini, O., \& Costa, G. (2013). Are regulations effective in reducing construction injuries? An analysis of the Italian context. Occupational and Environmental Medicine, 70(9), 611-616. http://dx.doi.org/10.1136/oemed-2012-101087. PMid:23503417.

Fehlberg, M. F., Santos, I., \& Tomasi, E. (2001). Prevalência e fatores associados a acidentes de trabalho em zona rural. Revista de Saude Publica, 35(3), 269-275. http://dx.doi.org/10.1590/S0034-89102001000300009. PMid:11486150.

Felce, A., Perks, S., \& Roberts, D. (2016). Work-based skills development: a context-engaged approach. Higher Education, Skills and Work-Based Learning, 6(3), 261-276. http://dx.doi.org/10.1108/HESWBL-12-2015-0058.

Fundação Coge - FUNCOGE. (2011). Relatorio de estatísticas de acidentes no setor elétrico brasileiro - síntese. Retrieved in 2018, January 31, from http://www.funcoge.org.br/comites/csst/wp-content/uploads/SinteseRelatorio2011.pdf

Gembalska-kwiecień, A. (2017). Fundamentals of an effective corporate safety culture. Ekonomia i Prawo. Ecomomics and Law, 16(4), 401-411. http://dx.doi.org/10.12775/EiP.2017.028.

Gonçalves, C., Fo., Souki, G. Q., \& Mello, J. R. C. A. (2017). Criminalidade no Brasil: Fatores influenciadores e ações mitigatórias. Curitiba: CRV Ltda.

Gra, C., \& Miha, M. A. (2011). Safety and health at work - major challenges in modern organizations. Land Forces Academy Review, 16(1), 66-75.

Hair, J. F., Anderson, R. E., Tatham, R. L., \& Black, W. C. (2009). Análise multivariada de dados (6. ed.). Porto Alegre: Bookman.

Heine, I., Beaujean, P., Schmitt, R., \& Aachen, R. (2016). Improving production ramp-up through human resource methods. The Quality Management Journal, 23(1), 7-19. http://dx.doi.org/10.1080/10686967.2016.11918459.

Heinrich, H. W. (1959). Industrial accident prevention: a scientific approach (3rd ed.). New York: Mcgraw Hill.

Hollnagel, E. (2009). Barreras y prevención de acidentes. Madrid: Modus Laborandi.

Hosseinian, S. S., \& Torghabeh, Z. J. (2012). Major theories of construction accident causation models: a literature review. International Journal of Advances in Engineering and Technology, 4(2), 2231-1963. 
International Labour Organization - ILO. (2016). Safety and health at work. Retrieved in 2016, December 12, from http://ilo.org/global/topics/safety-and-health-at-work/lang--en/index.htm

Jackson, J. M., Fo., Fonseca, E. D., Lima, F. P. A., \& Duarte, F. J. C. M. (2012). Organizational factors related to occupational accidents in construction. Work (Reading, Mass.), 41(Suppl 1), 4130-4136. http://dx.doi.org/10.3233/WOR-2012-0708-4130. PMid:22317355.

Kaiser, J. (2014). Dealing with missing values in data. Journal of Systems Integration, 42-51. https://doi.org/10.20470/jsi.v5i1.178.

Kazeminia, A., Kaedi, M., \& Ganji, B. (2019). Personality-based personalization of online store features using genetic programming: analysis and experiment. Journal of Theoretical and Applied Electronic Commerce Research, 14(1), 16-29. https://dx.doi.org/10.4067/S071818762019000100103.

Keffane, S. (2015). Communication's role in safety management and performance of the road safety practices. Jordan Journal of Civil Engineering, 9(2), 229-244.

Knudsen, F., \& Gron, S. (2010). Making sense of fishermen's risk perception. Policy and Practice in Health and Safety, 8(2), 77-94. https://dx.doi.org/10.1080/14774003.2010.11667749.

Koranyi, I., Jonsson, J., Rönnblad, T., Stockfelt, L., \& Bodin, T. (2018). Precarious employment and occupational accidents and injuries - a systematic review. Scandinavian Journal of Work, Environment \& Health, 44(4), 341-351. http://dx.doi.org/10.5271/sjweh.3720. PMid:29443355.

Kouvonen, A., Vahtera, J., Pentti, J., Korhonen, M. J., Oksanen, T., Salo, P., Virtanen, M., \& Kivimäki, M. (2016). Antidepressant use and work-related injuries. Psychological Medicine, 46(7), 1391-1399. http://dx.doi.org/10.1017/S0033291715002925. PMid:26804130.

Kurzthaler, I., Wambacher, M., Golser, K., Sperner, G., Sperner-Unterweger, B., Haidekker, A., Pavlic, M., Kemmler, G., \& Fleischhacker, W. W. (2005). Alcohol and/or benzodiazepine use: different accidents--different impacts? Human Psychopharmacology, 20(8), 583-589. http://dx.doi.org/10.1002/hup.736. PMid:16317801.

Lee, J. Y., Park, S., \& Baker, R. (2017). The moderating role of top management support on employees' attitudes in response to human resource development efforts. Journal of Management \& Organization, 3, 1-19. http://dx.doi.org/10.1017/jmo.2017.37.

Lehockey, K. A., Winters, A. R., Nicoletta, A. J., Zurlinden, T. E., \& Everhart, D. E. (2018). The effects of emotional states and traits on time perception. Brain Informatics, 5(2), 1-13. https://doi.org/10.1186/s40708-018-0087-9.

Liang, H., Lin, K. Y., Zhang, S., \& Su, Y. (2018). The impact of coworkers' safety violations on an individual worker: A social contagion effect within the construction crew. International Journal of Environmental Research and Public Health, 15(4), 1-22. http://dx.doi.org/10.3390/ijerph15040773. PMid:29673149.

Liu, C., Bartram, T., Casimir, G., \& Leggat, S. G. (2015). The link between participation in management decision-making and quality of patient care as perceived by chinese doctors. Public Management Review, 17(10), 1425-1443. http://dx.doi.org/10.1080/14719037.2014.930507.

Magnavita, N., \& Garbarino, S. (2017). Sleep, health and wellness at work: a scoping review. International Journal of Environmental Research and Public Health, 14(11), 1347. http://dx.doi.org/10.3390/ijerph14111347. PMid:29113118.

Motter, A. A., \& Santos, M. (2017). The importance of communication for the maintenance of health and safety in work operations in ports. Safety Science, 96, 117-120. http://dx.doi.org/10.1016/j.ssci.2017.03.020.

Muchiri, M. K., McMurray, A. J., Nkhoma, M., \& Pham, H. C. (2019). How transformational and empowering leader behaviors enhance workplace safety: a review and research agenda. Journal of Developing Areas, 53(1), 257-265. http://dx.doi.org/10.1353/jda.2019.0015. 
Mullen, J., Kelloway, E. K., \& Teed, M. (2017). Employer safety obligations, transformational leadership and their interactive effects on employee safety performance. Safety Science, 91, 405-412. http://dx.doi.org/10.1016/j.ssci.2016.09.007.

Munhê, V. P. C. (2009). Analise multicausal para compreensão de acidentes de trabalho; um studo de caso de uma empresa paranaense de alimentos (Dissertação de mestrado). Setor de Ciências Sociais e Aplicadas, Universidade Federal do Paraná, Curitiba.

Oliver, A., Cheyne, A., Tomás, J. M., \& Cox, S. (2002). The effects of organizational and individual factors on occupational accidents. Journal of Occupational and Organizational Psychology, 75(4), 473-488. http://dx.doi.org/10.1348/096317902321119691.

Pinion, C., Brewer, S., Douphrate, D., Whitehead, L., DelliFraine, J., Taylor, W. C., \& Klyza, J. (2017). The impact of job control on employee perception of management commitment to safety. Safety Science, 93, 70-75. http://dx.doi.org/10.1016/j.ssci.2016.11.015.

Pinto Silva, L., Angel Rivera Castro, M., Gilberto Dos-Santos, M., \& José Lima Neto, P. (2018). Commitment to work and its relationship with organizational culture mediated by satisfaction. Review of Business Management, 20(3), 461-487. http://dx.doi.org/10.7819/rbgn.v20i3.3947.

Prescod, D. J., \& Zeligman, M. (2018). Career adaptability of trauma survivors: the moderating role of posttraumatic growth. The Career Development Quarterly, 66(2), 107-120. http://dx.doi.org/10.1002/cdq.12126.

Rakhshandehroo, M., Mohdyusof, M. J., Tahir, O. M., \& Yunos, M. Y. M. (2015). The socialbenefits of urban open green spaces. Management Research and Practice, 7(4), 6071.

Rashid, R. A., Nordin, S., \& Salleh, R. (2014). Impact of safety communication on safety commitment with leader-member exchange quality as a moderating factor : a conceptual framework. Global Business and Management Research, 6(4), 277-282.

Sakina, A. K., \& Omar, A. (2018). Analysis of accident causes at construction sites in Oman. Jordan Journal of Civil Engineering, 12(2), 279-294.

Salminen, S. (2016). Occupational accidents: prevalence, risk factors and health outcomes. Journal of Risk and Governance, 4(3), 219-234.

Šarotar Žižek, S., \& Mulej, M. (2016). Creating a healthy company by occupational health promotion as a part of social responsibility. Kybernetes, 45(2), 223-243. http://dx.doi.org/10.1108/K-02-2015-0051.

Sawhney, G., \& Cigularov, K. P. (2018). Examining attitudes, norms, and control toward safety behaviors as mediators in the leadership-safety motivation relationship. Journal of Business and Psychology, 34, 237-256. http://dx.doi.org/10.1007/s10869-018-9538-9.

Sheikhalishahi, M., Azadeh, A., Pintelon, L., \& Chemweno, P. (2017). Human factors effects and analysis in maintenance: a power plant case study. Quality and Reliability Engineering International, 33(4), 895-903. http://dx.doi.org/10.1002/qre.2065.

Shen, B., Qu, W., Ge, Y., Sun, X., \& Zhang, K. (2018). The relationship between personalities and self-report positive driving behavior in a Chinese sample. PLoS One, 13(1), 1-17. http://dx.doi.org/10.1371/journal.pone.0190746. PMid:29324823.

Siren, A., \& Knudsen, S. G. (2017). Older adults and emerging digital service delivery: a mixed methods study on information and communications technology use, skills, and attitudes. Journal of Aging \& Social Policy, 29(1), 35-50. http://dx.doi.org/10.1080/08959420.2016.1187036. PMid:27215167.

Souza, L. S., Rocha, F. L. R., \& Mazzo, L. L. (2017). Clima organizacional e ocorrência de acidentes com materiais perfurocortantes num hospital público do Estado de São Paulo. Caderno Brasileiro de Terapia Ocupacional, 26(1), 85-95. http://dx.doi.org/10.4322/25268910.ctoAO1048. 
Tabachnick, B. G., \& Fidell, L. S. (2007). Using multivariate statistics (5th ed.). Boston: Pearson/Allyn \& Bacon.

Thurston, E., \& Glendon, A. I. (2018). Association of risk exposure, organizational identification, and empowerment, with safety participation, intention to quit, and absenteeism. Safety Science, 105(February), 212-221. http://dx.doi.org/10.1016/j.ssci.2018.02.012.

Tomás, J. M., Meliá, J. L., \& Oliver, A. (1999). A cross-validation of a structural equation model of accidents : organizational and psychological variables as predictors of work safety. Work and Stress, 13(1), 49-58. http://dx.doi.org/10.1080/026783799296183.

Valero Pacheco, I. C., \& Isabel Riaño-Casallas, M. (2017). Contributions of occupational health and safety to the quality of working life: an analytical reflection. Ciencia \& Tecnología para la Salud Visual y Ocular, 15(2), 85-94. http://dx.doi.org/10.19052/sv.4207.

Vu, H. M., Chan, H. K., Lim, M. K., \& Chiu, A. S. F. (2017). Measuring business sustainability in food service operations: a case study in the fast food industry. Benchmarking, 24(4), 10371051. http://dx.doi.org/10.1108/BIJ-04-2015-0030.

Yilmaz, F., \& Tosun, S. B. (2018). Evaluation of Safety Trends in Construction, Mining and Transportation Sectors in Turkey. Sigurnost, 60(1), 13-23. http://dx.doi.org/10.31306/s.60.1.2.

Zwetsloot, G. I. J. M., Kines, P., Ruotsala, R., Drupsteen, L., Merivirta, M. L., \& Bezemer, R. A. (2017). The importance of commitment, communication, culture and learning for the implementation of the Zero Accident Vision in 27 companies in Europe. Safety Science, 96, 22-32. http://dx.doi.org/10.1016/j.ssci.2017.03.001. 